\title{
65. Hanım! Görelim Neler Söylemiş: Dede Korkut Kitabı ve Beowulf destanlarının karşılaştırılmalı bir incelemesi
}

Fatoş Işıl BRITTEN1

APA: Britten, F. I. (2021). Hanım! Görelim Neler Söylemiş: Dede Korkut Kitabı ve Beowulf destanlarının karşılaştırılmalı bir incelemesi. RumeliDE Dil ve Edebiyat Araştırmaları Dergisi, (24), 1138-1149. DOI: 10.29000/rumelide.996054.

$\ddot{\mathbf{O} z}$

Geçmişin savaşçı kültürlerinin edebiyat alanındaki izdüşümü olan destanlar, anlatı türü olarak tanımlanabilmek için belirli birtakım özellikler sergilerler. Savaşçı, cesur ve neredeyse insanüstü özelliklere sahip kahramanların ekseninde gelişen olaylar savaşçı kültür kodları ile beslenir. Soylu akrabalardan oluşan yönetici sınıfa mensup savaşçıların hükümdarlarına her koşulda sadık kalması gerekirken hükümdarlarının onları ganimet, toprak veya diğer savaş yağmaları ile cömertçe ödüllendirmesi beklenir. Modern adalet sisteminin henüz oluşmadı̆̆ı zamanları hikâyelendiren destan kahramanları, toplumlarının içinden ya da dışından düşmanlara ve hatta ejderha ve devler gibi doğaüstü güçlere karşı kendinden yardım bekleyen halkları korumak zorundadır. Tetikte bekleyen ölüme karşı kazanılan her zafer, varoluşsal bir sevinci simgeleyen ziyafetlerle kutlanır. Dünya edebiyatında ilk ve orta çağ dönemlerine ait, çoğu sözlü gelenek ürünü, farklı coğrafyalarda ortaya çıkmış birçok destan bulunmaktadır. Bu destanlar anlatı türünün gerektirdiği ortak unsurları taşımalarına rağmen var oldukları kültürlerin aralarındaki farklılıklar sebebiyle birbirlerinden ayrışırlar. Bu çalışmada Türk edebiyat geleneğinin en önemli epik eserlerinden Dede Korkut Kitabı ile eski İngiliz edebiyatının en bilinen örneklerinden Beowulf destanı karşılaştırmalı edebiyat çerçevesinde ele alınacaktır. Dede Korkut Kitabı on üç boylamadan oluşur ve her boylamanın odağında farklı kahramanlar bulunmaktadır. Bu anlatıları bir araya getiren ve destanları birbirine bağlayan ana kahraman ise Oğuz toplumunun en saygın kişisi bilge Dede Korkut'tur. Çeşitli Anglosakson kabilelerinin ıstıraplarını anlatan Beowulf destanında ise olaylar bir kahramanın merkezinde gelişir. Bu iki destan evlilik, aile yapıları, kadın erkek ilişkileri gibi konularda Oğuz ve Anglosakson toplumlarına dair birçok detaya işaret eder.

Anahtar kelimeler: Karşılaştırmalı edebiyat, Dede Korkut Kitabı, Beowulf, destan

\section{Let us see, my khan, what's/he declaimed: A comparative analysis of The Book of Dede Korkut and Beowulf}

\begin{abstract}
Epic narratives, the projection of warrior cultures in the past in fiction, display certain features in order to be defined as a the genre of epic. The epic plot revolves around bold and almost superhuman heroes and unfolds through the maintenance and expression of warrior cultural codes. As enforcers for the ruling class of noblemen, warriors are required to obey their sovereign under any circumstances whilst in turn the sovereign is expected to reward his thanes generously with booty, lands and other spoils of war. The heroes of epic fiction, which recounts an era predating modern systems of justice, have to protect the tribe from its enemies, both within and outside their societies,
\end{abstract}

Ars. Gör. Dr., Trakya Üniversitesi, Edebiyat Fakültesi, Mütercim Tercümanlık Bölümü, İngilizce ABD (Edirne, Türkiye), fisilcihan@trakya.edu.tr, ORCID ID: 0ooo-0001-6020-2227 [Araştırma makalesi, Makale kayıt tarihi: 08.06.2021-kabul tarihi: 20.09.2021; DOI: 10.2900o/rumelide.996054]

Adres Address

RumeliDE Dil ve Edebiyat Araştırmaları Dergisi Osmanağa Mahallesi, Mürver Çiçeği Sokak, No:14/8 Kadıköy - ISTANBUL / TÜRKIYE 34714 e-posta: editor@rumelide.com

RumeliDE Journal of Language and Literature Studies Osmanağa Mahallesi, Mürver Çiçeği Sokak, No:14/8

Kadıköy - ISTANBUL / TURKEY 34714 tel: +90 $5057958124,+902167730616$

e-mail: editor@rumelide.com

phone: +90 $5057958124,+90216773$ o 616 
even against supernatural beings such as dragons and giants. Every victory in the face of death is celebrated with feasts, which symbolize a kind of existential joy. Various oral epics are present in world literature, that date back to ancient history and the middle ages. Although these narratives have some common features, as required by the conventions of the epic genre, there are also certain cultural differences between them. This paper, aims to analyse The Book of Dede Korkut, one of the most substantial epic works in the Turkish literary tradition and Beowulf, one of the the most recognized examples of old English literature with a comparative approach. The Book of Dede Korkut consists of thirteen mini epic narratives, each one promoting a different hero. These are linked by the sage Dede Korkut, the most esteemed character of Oghuz society, who appears in every narrative and thus brings these narratives together. On the other hand, in narrating the travails of various AngloSaxon tribes, Beowulf develops around one individual hero. These two epic narratives reveals numerous details about Oghuz and Anglo-Saxon societies regarding issues such as marriage, family structures, and gender relationships.

Keywords: Comparative literature, The Book of Dede Korkut, Beowulf, epic

\section{Giriş}

İnsan toplulukları arasındaki iletişimin çok kısıtlı olduğu ilk ve orta çağlarda üretilen en belirgin edebi türlerden biri hiç kuşkusuz destanlardır. Destanlar savaşçı kültürlerin kurgusal düzlemdeki yansımalarıdır. Destan türü bir yandan sanatsal boyut olarak bir yandan da döneminin insanlarının yaşayış şekillerini ve kültürel kodlarını anlamada işlevsel bir araç olarak çok katmanlı eserleri içinde barındırır. "Epiğin dünyası, ulusal kahramanlık geçmişidir: Ulusal tarihteki 'başlangıçların ve 'zirve dönemlerin' dünyasıdır, babaların ve aile kurucuların [...], 'ilkler’in ve 'en iyiler’in dünyasıdı’” (Bahtin, 2020: 167). Destan sözcüğü ise Farsça "Desitân" kelimesinden gelir ve bu epik manzum hikâyeler, diğer deyişle "[d]estanlar, henüz yazılı tarihin teşekkül etmediği dönemlerde [...] insanların ıstıraplarını, sevinçlerini, büyük göçlerini veya varlık yokluk mücadelelerini olağan dışı unsurlar aracılığıyla beyan ettikleri anlatılardır" (Gökdağ ve Üçüncü, 2015: 11).

Epik destan türünün belli başlı özellikleri bulunmaktadır. Bu eserlerde genellikle savaşçı bir erkek kahraman anlatının odak noktasıdır. Çoğunlukla korkusuz, gözü pek, güçlü kuvvetli bir yiğit olarak karşımıza çıkan kahraman kimi zaman Truva atı tuzağını kuran Odysseus gibi fiziksel kuvveti yerine zekâsıyla da adından söz ettirebilir. Diğer bir deyişle, kahraman sıradan biri değildir, genelden ayrılan insanüstü bir meziyeti vardır. Destan eski zamanlara ait bir edebi tür olduğu için romanlar gibi sıradan insanı ele almaz. Aksine “'yüksek' edebiyatın (yani, yönetici toplumsal grupların edebiyatının) çatısı altındaki” türlerden biridir (Bahtin, 2020: 157). Destanlardaki sıradan halktan karakterler ise (çoban, hırsız, hizmetçi gibi) hikâyeyi bir yere bağlamak için kullanılan yan karakterlerdir. Dolayısıyla, destan kahramanı doğuştan soyludur; ya bir kral ya da bir kralın veya beyin akrabasıdır. Dikkat çeken diğer bir öge ise kahramanın korku salan düşmanı öldürerek toplumda huzuru sağlamasıdır. Yani öldürme eylemi daha fazla can ve mal kaybı, aşağılanma ve ıstırap yaşanmaması için yapılması gerekendir.

Ortak diğer bir özellik ise güçlü akrabalık ilişkileridir. Tanınmayan ve bilinmeyenin korku saldığı ve varlığı tehdit ettiği bir dünyada insanın kendinden olana, benzer olana bağllığı oldukça anlaşılabilen bir durumdur. Kişiler eğer destan kahramanı değillerse tek başlarına savunmasızdırlar. Bu nedenle kendine benzer olanla birlikte hareket etmek ve topluluktan güç almak akıllıcadır. İnsanın ölümle her daim burun buruna olduğu bir ortamda destan kişilerine yaşama sevinci veren şey kutlama ve ziyafetlerdir. Her savaş galibiyetinden sonra çoğunlukla akrabalardan oluşan yönetici sınıfa mensup karakterlerin

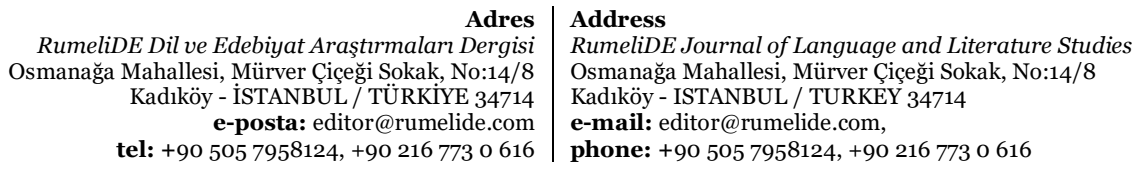


yiyip içtikleri şölenler ile hayata bağlandıklarını görürüz. Ölümün savaşla ve yaşamın şölenle sembolleştiği bu anlatılarda karakterler iki uç arasında salınırlar.

Destanlarda krallar ve onlara hizmet eden savaşçı topluluğu arasında belirli manevi prensipler bulunmaktadır. Buna göre savaş̧̧lardan beklenen, sadakat ve kralın emirlerine sorgusuz itaattir; krallardan ise cömert olmaları beklenir. Herhangi bir galibiyet sonrasında kral tarafından başarılı askerlere altın objeler ve değerli eşyalardan oluşan ganimetler verilir. Destan anlatıları farklı coğrafyalarda ortaya çıkmış olsa da cömertlik ve ganimet kavramı sıklıkla tekrarlanan ortak bir temadır. Bilge bir kral onun için savaşan kişilere ganimet haricinde toprak da vererek savaşçları onurlandırır ve onları ileriki dönemlerdeki savaşlar için heveslendirir. Sadakat ve cömertlik dışında yüceltilen diğer bir değerse övgüdür. Savaşçının hayatını her an kaybedebilir olması gerçeği övgü kavramı ile dengelenmeye çalışılır. Bu dünyada hatırlanmak, beğenilmek ve bir nevi ölümsüzlüğe kavuşmak ancak ileride övgü dolu hikâyelerin anlatılması yolu ile olacağı için savaş kahramanına övgü, savaşçııı onurlandırmanın ve bu dünyada ölümsüzlüğe ulaştırmanın tek yoldur.

Türk kültürüne baktığımızda Dede Korkut Destanı tema ve motif yönünden zenginliği ve çok çeşitli biçimsel özellikleri ile en ön plana çıkan destandır. Birleşik Krallık coğrafyasında ise bilinen ilk ve en ünlü destan Beowulftur; ancak Beowulf aslında Danimarka'nın kuzeyi ve İsveç’in güney taraflarını kapsayan bir bölgede geçen bir İskandinav destanıdır. İngiliz edebiyatı içinde kanonlaşmış olmasının sebebi destanın dilinin eski İngilizce olmasıdır. Beowulf da edebi iç ve dış özellikler bakımından oldukça zengin bir metindir ve Dede Korkut Destanı ile birçok unsuru benzeşir; ancak bu çalışma sadece koşutluklar değil farklılıklar üzerinde de durarak bu destanların ait oldukları toplumlara dair çıkarımlar yapma amacı taşımaktadır.

\section{Dede Korkut kitabr}

Onuncu ve on birinci yüzyllarda sözlü edebiyat geleneği olarak ortaya çıkan Dede Korkut hikâyeleri on dört ve on beşinci yüzyıllarda yazıya geçirilmiştir. Türk Dil Kurumu'nun "yiğit" ve "kahraman" olarak tanımladığı alpların, Oğuz toplumundaki kahramanlıklarını anlatan bu eserde düz yazı ile şiir bir arada kullanılmıştır (URL 1, 2021). Bu alpların "epitetleri ise hemen her zaman güçlü, korkusuz, yenilmez ve cömert sıfatları ile örülüdür” (Pehlivan, 2019: 220). Dede Korkut Kitabı'nın Dresden ve Vatikan olmak üzere sadece iki nüshası bulunuyordu. Toplamda on iki epik boydan diğer bir deyişle hikâyeden oluştuğu düşünülen epik eserin 2019 yılında Türkmen Sahra Nüshası keşfedilmiş ve on üçüncü “Salur Kazan'ın Yedi Başlı Ejderhayı Öldürmesi” adlı boy destana eklenmiştir. Pehlivan her ne kadar bir miktar "esneme" payı olsa da Dede Korkut destanını "ideolojik olarak" "temelde mükemmel zamanların, muhteşem insanlarının cesaret, sadakat, fedakârlık temelleri üzerinde yükselen hikâyeleri” olarak tarifler (2019: 492).

Hemen her boylamada bir destan kahramanı öne çlksa da tüm eser genelinde birden çok destan kahramanı vardır. Bu nedenle destana, destan kahramanının adı yerine bilge kişi konumundaki Dede Korkut'un (Korkut Ata) adı verilmiştir. Ali Öztürk, "Korkut adının elçi, öğütçü, Tanrı elçisi anlamı ile ilgili olabileceğini” ve "Ata” sözünün "Oğuzların dedeleri, ecdatları anlamında kullanıldığı gibi büyük hürmet, kutsiyet kazanmış halk bilgeleri ve şairleri, hâkimleri anlamına da” geldiğini belirtir (2019: 196). Dede Korkut karakteri hikâyeler arasında bir tutkal vazifesi görür. Kopuz çalıp manzume söyleyen ama aynı zamanda "ad veren, kız isteyen, tedavi eden ve dua eden yönleri ile Oğuzlar'ın başvurduğu Dede Korkut” destanda toplumun en saygın büyüğüdür. (Tunç, 2020: 159). Hana akıl verir, olayları

\footnotetext{
Adres | Address

RumeliDE Dil ve Edebiyat Araştırmalar Dergisi $\quad$ RumeliDE Journal of Language and Literature Studies Osmanağa Mahallesi, Mürver Çiçeği Sokak, No:14/8 $\quad$ Osmanağa Mahallesi, Mürver Çiçeği Sokak, No:14/8 Kadıköy - ÍSTANBUL / TÜRKIYE 34714 Kadıköy - ISTANBUL / TURKEY 34714 e-posta: editor@rumelide.com e-mail: editor@rumelide.com, tel: +90 505 7958124, +90 2167730616 phone: +90 505 7958124, +90 2167730616
} 
yönlendirir ve alplar üzerinde manevi olarak etkilidir, bu da onun bilge ve mistik özelliklerinden kaynaklanır (Öztürk, 2019: 217).

Dede Korkut karakterinin dikkat çeken özelliklerinden biri yukarıda belirtildiği üzere bir Oğuz geleneği olan genç yiğide isim vermektir. Oğuz kültüründe oğlan çocuklarına doğduklarında değil ancak baş kesip kan döktüklerinde yani bir başarı kazanıp kendilerini topluma ispat ettiklerinde isim konur. Örneğin Dirse Han’ın oğlu bir boğayı öldürünce Dede Korkut ona Boğaç Han adını verir. “Oğuz toplumu bir kişiyi kabullenmek için, onun atlı ve avcı göçebe kültürünün ideal tip özelliklerine kavuşmasını bekler [...] Yani mensubiyet şuuru kazanmasını, alp olmasını, ergenliğe geçmesini ister ve bu da genellikle törenle gerçekleşir" (Duymaz, 2020: 117). Bu törenlerin vazgeçilmezi olan ve destanlara adını vermiş Dede Korkut her destanın kapanışında kopuzu eline alarak son sözü söyler ve böylece destanlar arasında yapısal bir bütünlük oluşmasını sağlar.

Dede Korkut hikâyelerinin temel çatışma unsuru ise kâfirlerdir. Gürcistan civarında, Oğuzların yurduna yakın yerlerde yaşayan kâfirler; onların evlerini, mallarını yağmalama, Oğuz kadın ve erkeklerini esir alma firsatı kollarlar. "Salur Kazan'ın Evinin Yağmalanması Destanı’nda” anlatıldığı gibi Salur Kazan diğer beylerle birlikte "av avlayıp kuş kuşlamaya” gittiğinde casus hemen ihbarda bulunur (Demir, 2019: 138). Kâfir, insani boyutu neredeyse hiç olmayan oldukça kötücül bir varlık olarak karşımıza çıkar. Halkı dolayısıyla Oğuz beyini aşağılamak için pusuda bekleyen yırtıcı bir hayvan gibi hareket eder. Salur Kazan’ın eşi Burla Hatun, oğlu Uruz ve kızları ile birlikte esir alındığında kâfirlerin başı Şökli Melik, Burla Hatunu kâfirin döşeğine girmek veya oğlunun etini yemek gibi insan onurunu zedeleyecek, şeytani bir çatışmanın içinde bırakır. Farklı boylamalarda tekrar tekrar karşımıza çıkan Şökli Melik ve adamları "pasif durumda bir düşman tipi değil" aksine "saldıran taraf olur" (Duman, 2020: 163). Burada betimlenen düşman savaş̧̧ı, erkektir. Kâfirlerin kadınlarından ise Oğuz halkı bir zarar görmez. Güzel ve sevimli olarak tasvir edilirler. Bu kadınların görevi ziyafetlerde Oğuzlara kadeh sunmakla sinırlıdır. Destan boyunca kâfir kızlarının kâfir erkekleri ile işbirliği yaptığını hiç görmeyiz. Bu nedenle, hikâyelerde kâfir erkeklerine göre ikincil bir konumdadırlar. Kâfir erkeği oldukça çirkin, kötü ruhlu bir çatışma kaynağı iken kâfir kadınının edilgen, güzel ve sevimli olması ilginç ancak anlaşılabilir bir tezatlıktır; çünkü kâfir kadını savaşçı olmadığı için toplumu tehdit etmez.

Türk destanlarındaki kötü karakterlerin yüzde seksen birinin insan olduğu düşünüldüğünde ve cinsiyete göre dağılıma bakıldığında bu kötü insan karakterlerin yüzde seksen ikisinin erkek olduğu göz önüne alındığında destandaki en büyük çatışma kaynağının savaş̧̧ı kâfir erkeği olması olağandır. (Duman, 2020: 274-278). Ancak tepegözler, ejderhalar gibi doğaüstü varlıklar da Oğuz halkını zaman zaman sıkıntıya sokar. Örneğin; bir Oğuz çobanı, bir pınar perisi ile zorla ilişkiye girerek Ŏguzlara lanet getirir. Bu ilişkiden kolu bacağı belirsiz, gövdesinin üstünde tek bir gözü olan bir canavar doğar. Tepegöz kuşkusuz Oddesseia gibi eserlerden de aşina olduğumuz bir destan varllğıdır. Doymak bilmeyen iştahıyla Oğuzlardan yemek için günde altmış adam isteyen Tepegöz ile günde iki adam olarak uzlaşan bilge Dede Korkut'tur ancak Tepegöz’ü öldürerek toplumu bu büyük beladan kurtaran gözü pek savaşçı bir destan kahramanı olan Aruz beyin oğlu Basat'tır ve savaşçı erkek kahraman motifinin önemi bu destanda da vurgulanir.

Yukarıda bahsedilen Türkistan/Türkmen Sahra Nüshasının ve dolayısıyla on üçüncü boyun keşfedilmesiyle Dede Korkut Kitabı'ndaki canavar motifinin gücünün arttı̆̆ı yadsınamaz. "Salur Kazanın Yedi Başlı Ejderhayı Öldürmesi” başlı̆̆ından da anlaşıldığı gibi bu destan Salur Kazan'ın kâfiri yenmesi ile ilgili değil değişik kültürlerin mitlerinde sıklıkla karşımıza çıkan ejderha figürünü yok etmesi ile ilgilidir. Metin Ekici tarafından ilk olarak Nisan 2019'da “Dünya Mirası Dede Korkut Uluslararası

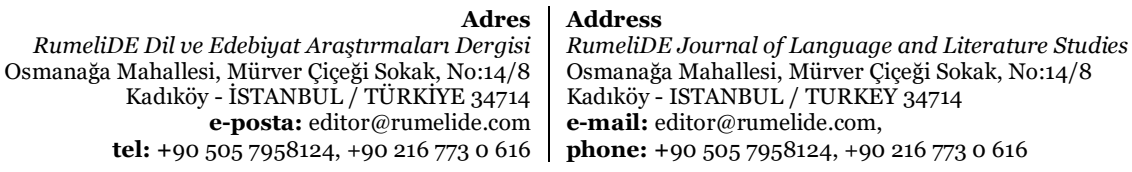


Sempozyumu"nda varlığı açıklanan metin gerek Türk edebi dünyası gerekse dünya edebiyatı anlamında oldukça sevindirici bir gelişmedir. Muhammed Veli Hoca’nın evindeki yazmayı Ekici'ye göndermesi ile ortaya çıkan bu nüsha Ekici tarafından Türkiye Türkçesine aktarılmıştır (2019: 10-13).

İlk kısmı Salur Kazan’ın ağzından birinci tekil şahısla ikinci kısmı ise genelde destanlarda görülen üçüncü tekil şahıs ile anlatılan bu son boyda Kazan öncelikle kâfir düşmanı yener. Her ne kadar Kazan: "O anda bile kahramanım, alım, erim diyerek övünmedim" diye iddia etse de önemli bir destan özelliği olan kendini övme bu boylamada da mevcuttur (Demir, 2019: 286). Haberci, Kazan'a on bin düşman geliyor dediğinde bu sayıyı ciddiye almaz sayı ta ki yüz bine ulaşıncaya kadar ancak o vakit bile endişelenmez ve bir hafta içinde düşmanı kılıcı ile yok eder. Sonrasında ise cömert bir beye yakışır şekilde onunla savaşan yiğitlere sancaklar ve bey unvanı gibi hediyeler verir. Destanın ikinci kısmında ise kâfir düşmanın yerini muhtemelen doğanın zorluk ve tehlikelerini simgeleyen canavar düşman alır. Av avlamaya giden Kazan av bulmak yerine yanan meşaleler ve dumanlar görünce o tarafa gider ve aynı Tepegöz gibi yerde yığın hâlinde yatan ejderhayı görür. Yardımcısı Lala Kılbaş’ın onu övgü dolu sözleriyle cesaretlendirmesi sonucu ejderhaya saldırmaya karar verir. Elbette savunmasız bir canlıyı öldürmek Türk savaş kültürünün mertlik kavramına uymayacă̆ı için ejderhayı önce uyandırır. Boğuşma sonrası Kazan "kara çelik sağlam" kılıcı ile destanda bazen yılan olarak da nitelendirilen ejderhanın boynunu keser (Demir, 2019: 288). Dökülen kanları gören Kazan’ın lalası Kılbaş beyinin öldüğünü zannedip endişelenir. Destan kodlarına uygun olarak minnetini ve sadakatini "ak ekmeğini çok yedim ağam” deyip ejderhayı öldürmek için kılıcına davranmasıyla ispatlar (Demir, 2019: 289). Lala Kılbaş destan kahramanının yiğit ve sadık yardımcısı rolüyle beyinin să̆ koludur. Ejderhanın derisi yüzdürülüp Kazan'a kıyafet dikilince Oğuz halkı Kazan'ın artık ejderha olduğundan şüphelense de bu çatışma kolaylıkla tatlıya bağlanır ve her Dede Korkut boylamasında olduğu gibi hikâye mutlu sonla biter ve Kazan’ın ünü bu dünyada kalsın diye Dede Korkut kapanışı şu sözlerle yapar: “Kazan gibi koçak yiğit bu dünyadan geldi, geçti” (Demir, 2019: 290).

Destan kahramanlarından birinin ölmesine yalnızca “İç Oğuz’a Dış Oğuz’un Asi olması ve Beyrek’in Ölmesi” boylamasında rastlarız. Bu destandaki çatışma unsuru ne kâfir düşman ne de canavarlardır. Boylamanın adından da belli olduğu gibi Oğuzların kendi iç çekişmelerinin bir sonucudur. Dış Oğuz beylerini temsil eden Aruz'un İç Oğuz beylerini temsil eden Kazan’a küsmesi nedeniyle ortaya çıan hikâye çatışmasında bu boylamanın kahramanı olan Beyrek'in Aruz tarafından öldürülmesi ile anlatı güçlenir. Beyrek iki tarafı barıştırmaya çalışan, beyi Kazan Salur'a hiçbir koşulda ihanet etmeyen itaatkâr bir yiğit olarak savaşçı destan kahramanının tipik bir örneğidir. Bu çatışmanın günahsız kurbanı olarak Oğuzlar'ın iki kolu arasındaki savaşın da sebebi olmuştur. Kazan bu boylamanın kötü adamı Aruz'u öldürerek Beyrek'in intikamını alır. Suçsuza adalet getirmek için intikam almak dünya edebiyatlarında genel olarak karşımıza çıkan önemli bir destan unsurudur. Modern adalet sisteminin henüz oluşmadığı eski zamanlarda kanı yerde bırakmama geleneği oldukça anlaşılır bir durumdur. Böylece bu dünyadaki adalet sağlanmış ve kötülüğe izin verilmemiş olur. Hikâyede kısaca betimlenen ölüm ritüeli, Oğuz kültürünü daha yakından tanımamıza olanak verir. Oğuz kültüründe önemli yeri olan atın kuyruğunun sahibinin vefatı ardından kesildiğini öğreniriz ve ölünün yakını kadınlar karalar giyerken erkekler kara giyip mavi sarınır ve ağlarlar. (Demir, 2019: 280).

Eski çağlarda insan topluluklarının doğaya daha yakın bir hayat sürmeleri nedeniyle modern toplumlara göre doğum, evlilik ve ölüm gibi süreçlerin hayatlarında daha merkezi bir konumda yer alması olağandır. Dede Korkut boylamalarında da öne çıan diğer bir kavram evliliktir. "Alp genç yaşta evlenir, evlilik onun olgunluğunu sağlayan aşamalardandır” (Demirel, 2015: 146). Aile kurma ve kadınlarla ilişkiler neredeyse savaşlar kadar Oğuz hayatının bel kemiğini oluşturur. Bu destanın diğer birçok yabancı

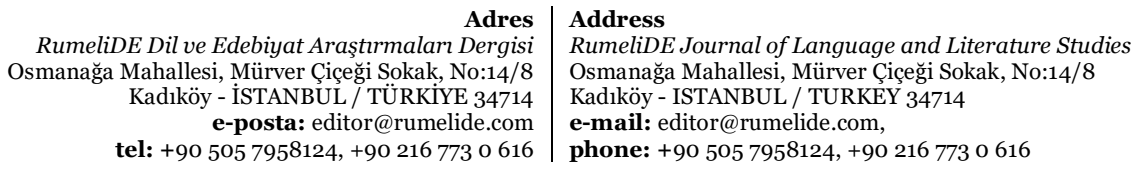


destandan farkı kadınların destanda oldukça görünür olmasında yatar. Üstelik kadınlar aşk hikâyeleri gibi romantik anlatılardan farklı olarak sadece ulaşılmaya çalışılan güzel genç kız olarak değil eş, arkadaş, anne ve hatta savaşçı olarak dolayısıyla daha çok boyutlu ve daha gerçekçi bir biçimde karşımıza çıkar.

Kam Püre Beyin oğlu Bamsı Beyrek destanında gençliği anlatılan Beyrek’in eş bulma süreci ayrıntılı bir şekilde işlenir. Beyrek hayalindeki kızı tariflerken romantik anlatılarda olduğu gibi güzelliğe ve dış görünüşe odaklanmaz. Kendisinden daha çevik bir şekilde ata binen, kendinden daha iyi savaşan bir kız düşler. Babası Püre Han: "Oğul sen kendine bir arkadaş, bir yoldaş istermişsin oğul" diyerek Oğuz kültüründeki kadın ve erkek arasındaki daha dengeli ve eşitlikçi ilişkiyi dile getirir (Demir, 2019: 161). Beşik kertmesi Banu Çiçek ile önce avlanır ve yarışırlar sonrasında ise pehlivanlar gibi güreşirler. Evlenmek olgusu Dede Korkut Destanı'nda sıklıkla karşımıza çıkar. Bamsı Beyrek ve Banu Çiçek hikâyesine benzer bir örnek Kanglı Koca Oğlu Kan Turalı Destanında ele alınır. Babası Kan Turalı'yı evlendirmek istediğinde Bamsı Beyrek gibi o da kendisinden daha atak, gerektiğinde kâfirin başını kesen, yiğit bir kız hayal eder ve narin, çıtkırıldım bir eş istemediğini belirtir. Evlendiği Selcen Hatun erkek destan kahramanı özelliklerini taşır. Cesur, gözü pek bir yiğittir. Dünya edebiyatının çeşitli coğrafyalarında ve tiyatro oyunu gibi farklı edebi türlerde çeşitli sebeplerle karşımıza çıkan kılık ve cinsiyet değiştirme motifine Dede Korkut'ta da rastlarız. Selcen Hatun düşmandan sakınmak için erkek kıyafetleri giyer. Sembolik açıdan bu eylem anlamlıdır. Selcen Hatun ve onun temsil ettiği Oğuz kadını erkek gibi kadınlardır. Cinsiyetler arasındaki geçiş daha akışkan ve toplumsal cinsiyet rolleri görece esnektir. Selcen Hatun düşmanı kah “önüne katıp kovalar” kah "basıp dağıt[ır]” ve Kan Turalı’yı atının arkasına atıp düşmandan kurtarır (Demir, 2019: 222-223). Hamide Demirel "Oğuz boylarında Türk kadınlarının be[y]lik de yaptıkların”" ve bu hatunlardan birinin "Boyu Uzun Burla Hatun" olduğunu belirtir (2015: 102). Gerçekten de destanda Burla Hatun güçlü ve kendinden emin bir profil çizer. Oğlu Uruz kâfire esir düşünce tereddütsüz bir şekilde düşman ile savaşmaya gider ve diğer Oğuz beyleri ile birlikte kâfirleri kılıçlar. Burla Hatun gibi kadınlar "gerektiğinde kocalarına akıl veren, ailenin ayakta durması ve devamlılığ için kocalarından daha fazla mücadele eden eş ve anne tipleridir" ve "ideal eş ve anne tipi kadına örnektirler” (Aksoy, 2020: 38). Gerek Uzun Boylu Burla Hatun gerekse Banu Çiçek ve Selcen Hatun gibi kadın karakterler, Salur Kazan, Kara Göne, Bamsı Beyrek gibi erkek karakterler kadar boylamaların merkezindedir ve kadın olmalarına rağmen savaşçı, yiğit erkek destan kahramanı profiline uyar.

Her ne kadar destanın kadınları anne, eş, arkadaş gibi rolleri ile toplumda erkeklerle iç içe ve neredeyse eşit bir hayat sürseler de kadınlık, erkeklik kadar değerli değildir. İç Oğuz, Dış Oğuz çekişmesinde Beyrek, Aruz'a: "Aldatarak er tutmak karı işidir, [k]arından mı öğrendin sen bu işi kavat” diyerek aldatma ve hile gibi olumsuz özellikleri kadınlık ile bağdaştırır (Demir, 2019: 279). Bu nedenle böylesine ataerkil bir toplumda kadınlardan da erkek gibi olmalarının beklendiği ve toplumsal cinsiyet olarak erkeksi özellikleri olan kadınların yüceltildiğini iddia etmek yersiz olmayacaktır.

Evlenmek kadar yuva kurmak, çocuk sahibi olmanın önemi de destanda sıklıkla yinelenir. Dirse Han Oğlu Boğaç Han Destanı’nda, Han Bayındır düzenlediği şölende: “[k]imin ki oğlu kızı yok kara otağa oturtun, kara keçe altına döşeyin, kara koyun yahnisinden önüne getirin, yer ise yesin; yemez ise kalksın, gitsin” diyerek çocuğu olmayan Oğuzları dışlar (Demir, 2019: 124). Bunun sebebi, Yüce Tanrı'nın çocuksuz kişilere beddua ettiği inancıdır. Benzer şekilde Bay Püre Bey de oğlu olmadığı için ağlar ve Tanrı'nın onu cezalandırdığını düşünür; ancak Oğuzlar erkek kadar kız çocuk sahibi olmak da isterler. Örneğin, Bay Piçen Bey Tanrı'dan bir kız evlat diler (Demir, 2019: 155). Bu nedenle, destana göre, ataerkil toplumlardan beklenen erkek çocuğun kız çocuğundan üstün görülmesi durumu Oğuz toplumu

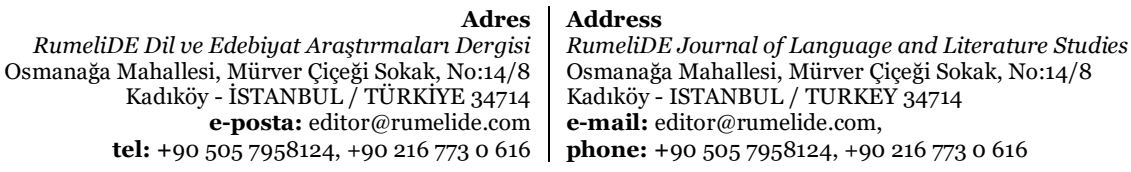


için geçerli değil gibi görünür. Çocuğu olmayan Dirse Han’a sorunun çözüm yolunu gösterense eşidir. Açları doyurup, kurbanlar kesmesi gibi ritüeller ile Tanrı'dan af dileme önerisi getiren kadın söylediklerinde haklı çıkar ve kısa zamanda çocuk sahibi olurlar. Bu bağlamda, soruna hanımın çözüm bulması Oğuz kadınının bilgeliğine bir göndermedir. Ataerkil ve erkekliğin yüceltildiği bir toplum olsa da Oğuzlarda kadın-erkek ilişkilerinde kadınların da sözünün dinlenebildiğini, güç dengeleri çokça asimetrik olmayan, daha eşitlikçi bir aile yapıları olduğu söylenebilir.

\section{Beowulf destanı}

Sözlü bir edebiyat ürünü olarak altıncı yüzyılda ortaya çıtığı düşünülen Anglosakson destanı Beowulf onuncu ve on birinci yüzyıllar civarında yazıya geçirilmiştir. Adından da anlaşılacağı üzere savaşçı kahraman Beowulf un hikâyesini anlatan destan bir toplum yerine bir bireyin hayatı etrafında şekillenir. "Beo" ve "wulf" sözcüklerinden oluşan isim Türkçede "aylkurt" anlamına gelmektedir ve destan kahramanının insanüstü gücüne bir göndermedir.

İki kısımdan oluşan destan, birinci kısımda Beowulfun gençliğine odaklanırken ikinci kısım elli yıl sonrasını Beowulf'un yaşlılık ve ölümünü anlatır. Anlatının iki parçadan oluşmasının nedeni ilk kısımda Beowulf'un ne kadar güçlü ve korkusuz bir kahraman olduğunu kanıtlamak, ikinci kısımda ise halkı uğruna hayatından vazgeçebilecek kadar iyi bir kral olduğunu gözler önüne sermektir. Çoğu destan gibi hikâyenin ortasından (in medias res) yani can alıcı yerinden başlayan Beowulf destanı, okuyucuya geri dönüşler (flashbacks) yoluyla Beowulf un hayatını daha geniş bir çerçeveden sunar. Buna göre Beowulf her ne kadar Got kralı Hygelac'ın yeğeni olarak kral soyundan gelse de Beowulf un ilk gençlik yıllarında kralın savaşçıları arasında ciddiye alınmadığını öğreniriz: "Hiç dikkat çekmemişti oysa uzun bir süre, koç yiğitler katında esamesi okunmazdı, içki salonunda kral bile kıymet vermezdi ona, cllız bir filiz olduğuna hemfikirdiler" (Heaney, 2020: 102). Sonrasında bir deniz canavarını öldürerek korkusuz, cesur bir yiğit olduğu yönünde ün kazanır; ancak kahramanlık ünü henüz tartışmasız kabul edilen bir olgu değildir. Dan halkına dadanan Grendel isimli yenilmez olduğu düşünülen canavarı öldürdüğünde ise gerçek bir ün kazanır ve savaşçı kahraman mertebesine yükselir.

Görüldüğü üzere bu destanda temel çatışma unsuru Dede Korkut Kitabı'ndaki gibi diğer kabileler değildir. Düşman kabilelerden bahsedilse de onlar, anlatının arka planında kalır. Beowulf un ötekileri, doğanın insanüstü gücünü simgeleyen canavarlardır. Beowulf un ilk galibiyeti bir deniz canavarına karşı olsa da destanda detaylı şekilde hikâyelendirilen ilk canavar Grendel'dir. Dede Korkut Destanı'ndaki kâfir erkekler gibi derin bir kötülüğü vardır bu canavarın: "İnsan yiyiciler, cinler, kötücül ruhlar ve devler" gibi Kabil'in lanetli soyundan gelen yaratıklardan biridir (Heaney, 2020: 42). Dede Korkut destanlarındaki toyların bir dengi olarak, şölenlerin yapıldığı Heorot isimli içki salonunda eğlenen Dan'lı savaşçılara musallat olmuş, tıpkı Tepegöz gibi doymak bilmez bir iştahla onları yığınlar hâlinde yemektedir:

Eski İngiliz şiirinin şölen sahnelerinde iki uçtan birine doğru bir yönelim olur. Bu sahneler bir tarafta mutluluğun tipik bir ifadesi olarak karşımıza çıkar [...] Hediyeler dağıtmak gibi ritüeller eşliğinde şölen sahneleri birlik ve beraberliği kutlayarak topluluğu birbirine bağlar. Diğer yandansa şölenler toplumsal bozulma ve parçalanma katalizörü haline gelebilir. [...] Beowulf ta da tam olarak bu durum gerçekleşir [...] neredeyse her şölende şiddet potansiyeli pusuda beklemektedir (Battles, 2015: 435). ${ }^{2}$

$2 \quad$ Kaynak metindeki alıntı şu şekildedir: 'In old English poetry, feaat scenes tend toward one of the extremes. On the one hand, they serve as the quintessential expression of joy. [...] Through accompanying rituals such as gift giving, feasting serves to establish and reaffirm the ties that bind the community together, celebrating social disruption and disintgration. [...] Precisely this happens in Beowulf [...] the potential for violence lurks near the surface of almost every feast'.

Adres Address

RumeliDE Dil ve Edebiyat Araştırmaları Dergisi $\quad$ RumeliDE Journal of Language and Literature Studies Osmanağa Mahallesi, Mürver Çiçeği Sokak, No:14/8 Osmanağa Mahallesi, Mürver Çiçeği Sokak, No:14/8 Kadıköy - İSTANBUL / TÜRKIYE 34714 Kadıköy - ISTANBUL / TURKEY 34714 e-posta: editor@rumelide.com $\quad$ e-mail: editor@rumelide.com, tel: +90 505 7958124, +90 216773 o 616 phone: +90 505 7958124, +90 216773 o 616 
Dede Korkut Kitabı'nda kâfirin çoğu zaman alp uykudayken saldırması ve alpın savunmasız kalmasına benzer şekilde Beowulf destanında da eğlencelerden sonra savaşçlar içkinin etkisiyle uykuya daldıktan sonra tekrar tekrar gafil avlanırlar. Ancak düşmana, yani Grendel'e odaklanacak olursak anlatının bu yaratığın bakış açısını anlamamıza vesile olacak bir alt metni okuyucuya sunduğunu da görülür. Grendel'in Heorot'a saldırmasının sebebi oradan gelen yüksek şenlik sesleridir. Mağara karanlığında yaşayan yaratık bu zorluğa bir süre acı ile katlanır. Salondan harp ve ozanın şarkısının sesleri gelmektedir (Heaney, 2020: 28).34 Burada bahsedilen zorluk ve acı, fiziksel olabileceği gibi duygusal da olabilir çünkü Grendel toplumdan dışlanmıştır ve bir yurdu yoktur. Sınırlarda, bataklıklarda gezen insan formuna yakın bir görüntüsü olan ama insanlardan farklı, yalnız ve mutsuz bir yaratıktır. Bir arada gülüp eğlenen, yiyip içen insanlar onu aralarına almaz. Bu nedenle kininin ve gaddarlı̆̆ının nedeni yüksek sese tahammülsüzlük kadar dışlanmışlık olabilir. Bu bağlamda Beowulf metni, her ne kadar karakter oluşturmayı diğer destanlar gibi oldukça yüzeysel bir iyiler ve kötüler ayrımı ile yapsa da kötünün neden kötü olduğuna dair çıkarımda bulunmamıza olanak vermesi açısından değerlidir. Vücut yapısı amorf Grendel, görünüşü farklı olduğu için toplumdan dışlanan insanları temsil eder ve bir anlamda yabancllk kavramının bir alegorisidir.

Kazanan taraf olan Beowulf, insanüstü gücünün ve kendine güveninin bir göstergesi olarak silahsız, çıplak elleriyle yaratığı öldürdüğünde, Grendel’in kendisi gibi canavar annesi, oğlunun öcünü almak için Hrothgar'ın en sevdiği hizmetkârlarından birini katleder. Bunun üzerine Beowulf "yas tutmaktan yeğdir öç almak" düsturu ile hareket eder ve karşımıza savaşçı pagan kültürünün en belirgin özelliklerinden biri olan öç kavramı çlkar (Heaney, 2020: 79). Savaşçı, feodal destan kültüründe kanın yerde kalmaması oldukça önemli bir töredir ve Beowulf, aynı Salur Kazan'ın Beyrek'in intikamını alması gibi bir gereklilik ile davranır. Beowulf'un canavar anneyi de öldürmesi üzerine canavarlar ile insanlar arasında gelişen kan davası uzamaz ve yaklaşık elli yıl sürecek canavarların musallat olmadığı bir barış dönemi hâkim olur.

Anlatının son kısmında Beowulf karşımıza genç ve hırslı bir savaşçıdan ziyade halkını korumak isteyen yaşlı bir Got kralı olarak çıkar. Huriye Reis "destanlar, yaşlı karakterlerin destan gerçekliği içinde yaşadıkları zorlukları ve kaybettikleri maddi ve manevi gücü yaşlıya gösterilen saygı ve yaşlı kişilerin bilgi ve tecrübesini vurgulayarak telafi etme eğilimi gösteren anlatılardır" diye tanımlar (2011: 36). Bu bağlamda, Beowulf da yaşlandığı için gücünü bir miktar kaybetmiştir; ancak anlatının ikinci kısmında karşımıza çıkan kahraman, bu olumsuzluğu bilgelik ve tecrübesi ile kapatmakta ve oldukça saygı görmektedir. Beowulf'un bu sefer savaşacağı düşman ise Dede Korkut hikâyesinde de yer alan ejderha gibi Got ülkesine dadanmış, destanlardaki mübalağalı anlatımdan nasibini almış, "kafadan kuyruğa tam on beş metre" bir yaratıktır ve Beowulf, Salur Kazan gibi bu ejderhayı öldürmek zorundadır (Heaney, 2020: 125). Beowulf yanındaki adamların kaçması üzerine ejderhanın inine tek başına girerek cesaretini bir kez daha kanıtlar. Tıpkı Kılbaş gibi onun da Wiglaf isimli bir sağ kolu vardır ve Wiglaf yine destan kodlarına uygun davranarak kralına sonuna kadar sadık kalır. Ne var ki Beowulf ejderhayı öldürmeyi başarsa da bu çatışmadan Salur Kazan gibi tam bir galibiyet ile çıkamaz ve ölür.

Dede Korkut Kitabı'nın Bamsı Beyrek Boylaması'nda karşımıza çıkan cenaze sahnesi Beowulf destanında Beowulfun ölümü ile ilgilidir. Anglosakson savaşçı kültürde savaşarak ölmek bir onur olduğu için cenaze kısmı ayrıntılı olarak tasvir edilir. Ölünün ardından ağıtlar yakmak, cesedi eşyaları

\footnotetext{
3 Bu alıntı kaynak metinde şu şekilde geçmektedir: 'Then the fierce spirit painfully endured hardship for a time, he who dwelt in the darkness, for every day he heard loud mirth in the hall; there was the sound of the harp, the clear song of the scop'.

$4 \quad$ Bu kısım Türkçe erek metinde bulunmaz. O nedenle İngilizce kaynak metinden alıntı yapılmıştır. Adres Address

RumeliDE Dil ve Edebiyat Araşttrmaları Dergisi $\quad$ RumeliDE Journal of Language and Literature Studies Osmanağa Mahallesi, Mürver Çiçeği Sokak, No:14/8 $\quad$ Osmanağa Mahallesi, Mürver Çiçeği Sokak, No:14/8 Kadıköy - İSTANBUL / TÜRKIYE 34714 Kadıköy - ISTANBUL / TURKEY 34714 e-posta: editor@rumelide.com $\quad$ e-mail: editor@rumelide.com, tel: +90 $5057958124,+902167730616$ phone: +90 505 7958124, +90 2167730616
} 
ile birlikte yakıp küllerini mezarın içine koymak gibi toplumun ölüm ritüellerine dair bilgi ediniriz. Beowulf'un varlı̆̆ halkına can ve mal güvenliği verirken onun yokluğu herkesi savunmasız bırakır. Hiç şüphesiz, Got halkı için hayat bu insanüstü güce sahip kahraman olmadan çok daha çetin olacaktır. Destanda sadece canavarlar ile yapılan savaşlar anlatılsa da Beowulf un yokluğunda İsveçliler, Franklar, Frizyalılar gibi farklı milletlerle savaş tehlikesi öngörülmektedir. "Kan, kölelik ve her türlü horlanma" korkusu okuyucuya Oğuzlar’ın daimi olarak kâfirler tarafından esir alınıp aşağılanma ve çatışmalarda ölme tehdidi altında yaşamalarını çağrıştırır (Heaney, 2020: 128).

Genç bir savaşçıdan yaşlı bir krala dönüşen Beowulf bir kraldan beklenen cömertliği işaret eden "Yüce Yüzük Bahşeden", "Yüzük Yağdıran" gibi sıfatlarla anılır (Heaney, 2020: 124). Wiglaf da Kılbaş gibi minnettarlıkla efendisinin kendisine bolca verdiği hediyeleri düşünür. Beowulf "eli açık", "merhametli", "mantıklı" ve "şefkatli" olmak gibi ideal bir kraldan beklenen tüm özelliklere sahiptir (Heaney, 2020: 128-129). Bunun yanında günümüz okuyucusunu yadırgatabilecek bir özelliği daha vardır: "[h]erkesten daha heveslidir şöhrete" (ibid). Şöhret ve övgü destan kahramanının temel besini gibidir. Yukarıda belirtildiği üzere hayatın bir ölüm kalım savaşı olduğu zamanlarda savaşçı kahramanlar kalıcı övgü, şöhret ve kendisinden sonraki nesillere hikâyeler yoluyla tanıtılma gibi bir motivasyon ile yaşarlar. Ayrıca metin her ne kadar Hristiyanlığın erken dönemlerinde kaleme alınmış olup yer yer tek tanrılı din özellikleri gösterse de Beowulf destanı Hristiyanlık öncesi, çok tanrılı çağlarda oluşmuştur. Bu nedenle, ahiret inancının gelişmediği dönemlerde ölümsüzlüğün tek yolunun övgüler yoluyla kalıcı şöhret olması oldukça anlaşlabilir bir durumdur.

Feodal ve dolayısıyla ataerkil bir toplumun ürünü olan Beowulf ta hemen hemen tüm karakterler erkektir. Askerlik ile ilgili sözcüklerin sıklıkla kullanıldığı savaş merkezli ve maskülen bir atmosfere sahip anlatıda var olan kadın karakterler oldukça silik ve geri plandadırlar. Genel olarak baba, oğul, amca, dayı ve erkek yeğenlerin oluşturduğu erkek akraba topluluklarının birlikte savaşıp birlikte eğlendikleri destanda en görünür kadın karakter Hrothgar'ın karısı kraliçe Wealhtheow'dur. Wealhtheow, Helmings ve Scyldings kabilelerine barış getirmesi amaciyla Hrothgar ile evlendirilmiş bir "barış dokuyucu"dur. "Barış dokuma" (peace weaving) âdeti kız alıp verme yoluyla iki düşman kabilenin evlilik bağı oluşturması ve savaşların son bulması amacına işaret eder. Christopher Fee "bir kral [...] kızının veya başka bir kadının satışıyla barışı takas etme girişıminde bulunur” diye açıklar ve Orta Çă Anglosakson toplumunda kadının bir meta gibi görülmesine dikkat çeker (Fee, 1996: 290). Çocuk ise bu barışın bir teminatıdır: "Hayattaki çocuğun bedeni anne babası tarafından iki parçaya ayrılamayacağına göre çocuk yaşadı̆̆ı sürece insanlar, kabileler ya da uluslar arasındaki anlaşma devam edecek ve "barış dokuma' geleneği başarılı olacaktır" (Drout, 2007: 207). Wealhtheow "altın taçlı" gibi sıfatlarla bir kraliçeye yakışacak şekilde ve maddi güç sembolü altın takıları ile betimlenir (Heaney, 2020: 72). "Wealhtheow'un sosyal görevi hükümdara ve hükümdarın toprak sahibi yaptığı feodal efendiye sorumluluklarını hatırlatmaktı[r] ancak görevi asla gerçekten yüzük veren kişi olmayı kapsamaz [...] bu Hrothgar'ın görevi[dir]" (Fee, 1996: 289)5. Ayrıca kraliçe'nin Heorot içki salonunda kupalarla erkeklere içki sunduğunu öğreniriz. Bu açıdan Wealhtheow, Dede Korkut Kitabı'ndaki Oğuzlara kadeh sunan kâfir kızları gibidir fakat Dede Korkut Kitabı'ında içki sunmak "aşağılık bir iş"ken Beowulf destanında ideal bir kraliçenin ya da kızı Freawaru gibi asil kadınların en önemli görevlerinden biri altın işli kupalarla erkeklere sunum yapmakla sinırlıdır (Pehlivan, 2019: 248). Metinde Wealhtheow az da olsa konuşur. Oğullarından ve onların geleceğinden bahseden barış dokuyucu kraliçenin içki sunmak dışındaki aktif tek rolü anneliktir.

\footnotetext{
$5 \quad$ Alıntı kaynak metinde şu şekildedir: 'Wealhtheow's social function includes reminding the lord and thane of their responsibilities, but does not extend to actual ring-giving itself; that [...] is Hrothgar's function'.

Adres Address

RumeliDE Dil ve Edebiyat Araştrrmalar Dergisi $\quad$ RumeliDE Journal of Language and Literature Studies Osmanağa Mahallesi, Mürver Cicçeği Sokak, No:14/8 Osmanağa Mahallesi, Mürver Çiçeği Sokak, No:14/8 Kadıköy - ISTANBUL / TURKIYE 34714 Kadıköy - ISTANBUL / TURKEY 34714 e-posta: editor@rumelide.com $\quad$ e-mail: editor@rumelide.com, tel: +90 505 7958124, +90 216773 o 616 phone: +90 505 7958124, +90 216773 o 616
} 
Wealhtheow haricinde görünür olan başka bir dişi varlık Grendel'in annesidir. Ancak o da oğlu üzerinden tanımlanır ve bir adı bile yoktur. Destandaki rolü Wealhtheow gibi annelik üzerine kuruludur. Gwendolyn Morgan, Grendel’in annesinin kadının anne olarak baskın, güçlü, ezici yanını temsil ettiğini ve hatta sevgili rolünde baştan çıarıcı kadın arketipi ile özdeşleştirebileceğini vurgular ve "görünüşe göre, kadın gücü hem anne olarak hem de sevgili olarak Anglosakson erkeği bakış açısına göre ölümcüldür ve yok edilmesi gerekmektedir" diye belirtir (1991: 59)6. Oldukça ataerkil bir dönemi hikâyeleştiren bu destanın dünyasında kadının baskın ve güçlü yanlarının bir canavar ile sembolleştirilmesi ve onun erkek kahraman tarafından öldürülmesinin şaşırtıcı olduğu söylenemez.

Bir yanıyla Wealhtheow'u diğer yanıyla Grendel'in annesini çağrıştıran, destanda bir karakter olarak değil de efsanevi bir kraliçe olarak bahsi geçen Kraliçe Modthryth ise, tehlikeli, kötü kadın tipinden ideal kadın tipine geçiş yapar. Femme fatale kadın tiplemeleri gibi baştan çıkarıcı güzellikteki Modthryth, kendisine yan gözle bakan erkekleri türlü işkencelerden geçirtip öldürtür ancak kral Offa ile barış dokumak için evlendikten sonra durulur ve "az bela kesilir, daha az gaddar olur [...] takip eden ylllarda [...] yaptığı iyilikler, yaşama tarzı övgüler al[ır]” (Heaney, 2020: 95). Destan metni, bu kadın üzerinden kadınların nasıl davranması gerektiğini didaktik bir dille anlatır: "Güzelliği dillere destan bir kraliçe dahi öyle aşmamalı haddini. Aksine barış dokumalı, dokunmamalı masum halkın hayatına hayali hakaretlerle" (ibid.). Tüm bu örneklerden görüleceği üzere destan kadınları, Anglosakson toplum normlarma uygun olarak ideal eş ve anne ya da tehlikeli, erkekleri felaketlere sürükleyen kötücül kadınlar olarak basit ve derinliksiz şekilde iki kategoriye ayrılmıştır.

Eş ve evlat sahibi olmanın savaşlarda galibiyet kazanmak kadar mühim olduğu Dede Korkut Kitabı'nın aksine Beowulf ta evlenme ve yuva kurma kavramları üzerinde pek durulmaz. Destanda akrabalı ilişkilerinin güçlü olduğu bir toplum tasvir edilse de Beowulf'un kral olmasına rağmen ne eşi ne de çocuğu vardır. Metinde bu durumla ilgili herhangi bir yargı veya yorum yer almaz. Kahraman, ölümünden sonra krallığı ejderha saldırısında ona yardım eden sadık hizmetkârı ve uzak akrabası Wiglafa bırakır ve böylelikle krallık sahipsiz kalmamış olur.

\section{Sonuç}

Bu çalışmada, Türk ve İngiliz toplumlarına ait iki önemli Orta Çağ destanı olan Dede Korkut Kitabı ve Beowulf destanı karşılaştırılarak benzerlik ve farklılıklar bağlamında tespitlerde bulunmak ve bunun sonucunda bu destanların ortaya çıtıkları toplumların özelliklerine dair çıkarımlar yapmak hedeflendi.

Destan anlatı türünün ortak temalarını içerdiği ve savaşçı kültürleri hikâyelendirdiği için her iki anlatıda birçok benzerlik vardır. Örneğin; Dede Korkut Kitabı'nda yiğit, korkusuz alplar ve Beowulf ta savaş̧̧ı, gözüpek Beowulf ana karakterlerdir, asla yanlış yapmazlar ve belli bir ideali temsil ederler. Ayrıca, bu destanlarda cenaze ritüelleri gibi o dönemin geleneklerine şahit oluruz. Beowulf'un cesedi törenle yakılıp ardından ağıtlar söylenirken Beyrek’in ölümünden sonra atının kuyruğunun kesildiğini ve insanların yas kıyafeti olarak siyah giydiğini öğreniriz. Bunun dışında, ortak düşman olarak karşımıza ejderha motifi çıkar. Beowulf ve Salur Kazan, halklarına tehlike getireceklerini düşündükleri ve de övgü alacaklarını bildikleri için bu ejderhalara saldırırlar ve bunu yaparken să̆ kolları Wiglaf ve Lala Kılbaş'tan yardım alırlar. Wiglaf ve Lala Kılbaş sadakatleri ile Beowulf, Hrothgar, Salur Kazan, Bayındır Han gibi yöneticiler ise cömertlikleri ve cesaretleri ile destan kodlarına uygun davranırlar.

\footnotetext{
6 Bu alıntı kaynak metinde şu şekilde geçmektedir: 'Apparently, feminine power, both as mother and as lover, is deadly in the view of the Anglo-Saxon male, and thereby necessitates its own destruction'.

Adres Address

RumeliDE Dil ve Edebiyat Araştrrmalar Dergisi $\quad$ RumeliDE Journal of Language and Literature Studies Osmană̆a Mahallesi, Mürver Çiçeği Sokak, No:14/8 Osmanağa Mahallesi, Mürver Çiçeği Sokak, No:14/8 Kadıköy - ISTANBUL / TURKIYE 34714 Kadıköy - ISTANBUL / TURKEY 34714 e-posta: editor@rumelide.com $\quad$ e-mail: editor@rumelide.com, tel: +90 $5057958124,+902167730616$ phone: +90 505 7958124, +90 2167730616
} 
Farklılıklar bağlamında ilk olarak Dede Korkut Kitabı'nın, çoğu yönetici sınıf mensubu olsa da genel olarak Oğuz toplumunu merkeze koyup farklı kahramanları ön plana çıkarırken Beowulf un bir kahramanın başına gelen olaylar üzerinden şekillendiğini söyleyebiliriz. Bunun sebebi Oğuzlarda toplum ilişkilerinin ve sosyal bağların hayli güçlü olmasından kaynaklanıyor olabilir. Diğer bir farklılık Dede Korkut Kitabı'nda ise, temel çatışma unsuru kâfir erkekleriyken ve tamamen kötücül olarak tasvir edilmişlerken, Beowulf destanında temel çatışmanın doğaüstü varlıklardan kaynaklanmasıdır. Bu yaratıklardan Grendel oldukça zalim olmasına rağmen metin okuyucuya bu yaratıkla empati kurma imkanı verir. Aynı şekilde Grendel’in annesinin de öldürülen oğlunun öcünü almak istemesi olağandır. Bu noktada Beowulf metninin düşman kavramını biraz daha az siyah beyaz çizdiğini ve düşman da olsa bu karakterlerle bir noktaya kadar empati kurulabildiğini söyleyebiliriz.

Her ne kadar anne canavar, intikam için saldırıda bulunsa da Got ya da Dan halkının kadınlarının hiçbir şekilde Oğuz kadını gibi at üzerine, elinde kılıç ile savaştı̆̆ını görmeyiz. Belli ki erkeklerle yoldaşlık, birlikte savaşma ve hatta gerektiğinde erkekleri düşmandan koruma gibi özellikler destanda betimlenen Anglosakson kadınlarının özellikleri arasında bulunmaz. Soylu kadınların kabileler arasındaki savaşı durdurmak için evlendirilmek ve annelik yapmak dışındaki görevleri savaşçılara kadeh sunmak ile sınırlandırılmıştır. Halbuki Oğuz kadını erkekler kadar sosyal hayatta aktif ve görünürdür. Kadın erkek arasındaki ilişkiler ataerkil döneme rağmen oldukça eşitlikçidir. Kadının anne rolü haricinde arkadaş, yoldaş, savaşçı ve yönetici özellikleri vardır. Kadınlar eşlerine akıl verebilir ve bu erkek için kırıcı bir durum değildir. $\mathrm{Bu}$ bakımdan destan incelemelerinden anlaşıldığı kadarıyla Oğuz toplumunda, dönemin Anglosakson toplumuna göre çok daha az cinsiyet ayrımcılığı görülmektedir.

Dede Korkut Kitabinda evlenmek, yuva kurmak, çocuk yetiştirmek düşmanla savaşmak kadar önemlidir. Destanda bu konulara sıklıkla yer verilmiş ve önemi vurgulanmıştır. Beowulf destanında ise Beowulf'un evlendiğine veya çocuk sahibi olduğuna dair herhangi bir bilgi verilmez. Eğer Beowulf Oğuz toplumunda yaşasaydı muhtemelen bu özellikleriyle Oğuzlardan, kendi toplumunda gördüğü saygıyı göremezdi. Anglosakson toplumunda savaş, erkekler ile özdeştirildiği için Dede Korkut Kitabı’nın tersine, Beowulf metni kadınların dünyasına ait detaylar ile arasına oldukça keskin bir mesafe koyar. Bu nedenle, Orta Çă̆ dönemi Anglosakson toplumunda kadınlar belirgin şekilde ikincil bir konumda olduklarından kadınlar ile olan ilişkileri daha görünür kılan aile içi ilişkiler üzerinde neredeyse hiç durulmamıştır.

\section{Kaynakça}

Abrams, M. H. (1993). The Norton Anthology: English Literature. Volume 1. New York and London: W.W. Norton \& Company.

Aksoy, H. (2020). Destan Dünyasında Kadın: Kirgız Destanlarında Kadın Tipler. Ankara: Kömen Yayınları.

Bahtin, M. (2020). Karnavaldan Romana: Edebiyat Teorisinden Dil Felsefesine Seçme Yazılar. (çev. Cem Soydemir). İstanbul: Ayrıntı.

Battles, P. (2015). Dying for a Drink: "Sleeping after the Feast" Scenes in Beowulf, Andreas, and the Old English Poetic Tradition. Modern Philology, 112(3), 435-457. doi:10.1086/678694

Demir, N. (2019). Dede Korkut Destanı. İstanbul: Ötüken Neşriyat.

Demirel, H. (2015). Türk Destanlarmın Ana Unsurları. İstanbul: Ötüken Neşriyat.

Duman, M. (2020). Türk Halk Anlatmalarmda Olumsuz Tipler: Mit, Destan, Halk Hikâyesi. İstanbul: Ötüken Neşriyat.

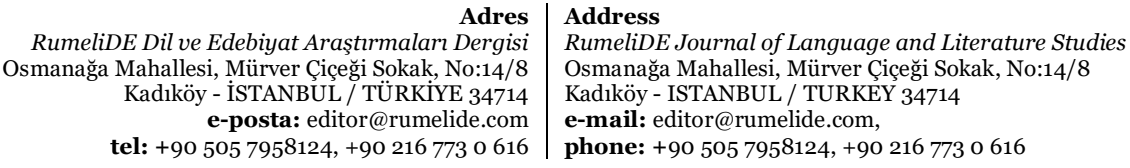

RumeliDE Dil ve Edebiyat Araştırmalar Dergisi

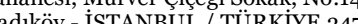
tel: +90 $5057958124,+902167730616$ 
Duymaz, A. (2020). “Dede Korkut Kitabı’nda Alplı̆̆a Geçiş ve Topluma Katılma Törenleri Üzerine Bir Değerlendirme”, İslamiyet Öncesi Türk Destanlarl. (Hazırlayanlar Salim Sakaoğlu, Ali Duymaz).

İstanbul: Ötüken Neşriyat.

Ekici, M. (2020) Dede Korkut Kitabı Türkistan/Türkmen Sahra Nüshası Soylamalar ve 13. Boy. İstanbul: Ötüken Neşriyat.

Fee, C. (1996). "Beag \& Beaghroden": Women, Treasure and the Language of Social Structure in "Beowulf". Neuphilologische Mitteilungen, 97(3), 285-294.

Gökdağ, A. B. ve Üçüncü, K. (2015). Başlangıcından Günümüze Türk Destanları. Ankara: Akçağ Yayınları.

Heaney, S. (2020). Beowulf. (çev. Nazmi Ağıl). İstanbul: Yapı Kredi.

Morgan, G. (1991). Mothers, Monsters, Maturation: Female Evil in Beowulf. Journal of the Fantastic in the Arts, 4(1 (13)), 54-68.

Öztürk, A. (2019). Çağlar İçinde Türk Destanları. İstanbul: Pozitif.

Pehlivan, G. (2019). Dede Korkut Kitabinda Yapı, İdeoloji ve Yaratım: Dresden ve Vatikan Nüshalarını Mukayeseli Bir İncelemesi. İstanbul: Ötüken Neşriyat.

Reis, H. (2011). "Dede Korkut Kitabı ve Beowulf Destanında Yaşlılık ve Yaşlanma”, Millî

Folklor. 12(91), 25-36.

Tunç, Z. (2020). "Dede Korkut Kitabı'nda Şamanik Unsurlar”. Avrasya Uluslararası Araştırmalar Dergisi. 8(25), 142-163. DOI: 10.33692/avrasyad.839712

URL 1. Erişim Tarihi: 8 Mayıs 2021, (https://www.sozluk.gov.tr).

RumeliDE Dil ve Edebiyat Araştırmaları Dergisi Osmanağa Mahallesi, Mürver Çiçeği Sokak, No:14/8 Kadıköy - İSTANBUL / TÜRKIYE 34714 e-posta: editor@rumelide.com tel: +90 $5057958124,+902167730616$
Address

RumeliDE Journal of Language and Literature Studies Osmanağa Mahallesi, Mürver Çiçeği Sokak, No:14/8

Kadıköy - ISTANBUL / TURKEY 34714

e-mail: editor@rumelide.com,

phone: +90 5057958124, +90 2167730616 